Published by LPMP Imperium

Journal homepage: https:/ / ejournal.imperiuminstitute.org/ index.php/ JMSAB

\title{
Pengaruh sales promotion terhadap JMSAB impulse buying konsumen
}

\author{
Rita Zahara \\ Program Studi Manajemen, STIE Pengembangan Bisnis dan \\ Manajemen \\ Paper type \\ Research paper
}

\begin{abstract}
This research is conducted to analyze the influence of sales promotion on impulsive buying at $\mathrm{ABC}$ Hypermarket in East Jakarta. The aims of this research is also to know the sales promotion that influence the impulse buying, supporting factors and how the problems take place. The descriptive-verificative method is used in this research. Data collection methods are literature and field studies. Field study covers observation, interview and structural questionnaires. The questionnaires are given to 45 consumers at $\mathrm{ABC}$ Hypermarket in East Jakarta. The sistematic sampling is used as sampling technique. Data are analyzed by qualitative analysis and correlation regresion analysis. The analysis confirms that there are influences of sales promotion on impulse buying at $\mathrm{ABC}$ Hypermarket in West Jakarta. That is, if sales promotion is carefully done, it will increase impulse buying
\end{abstract}

\begin{abstract}
Abstrak
Tujuan dari penelitian ini adalah juga untuk mengetahui promosi penjualan yang mempengaruhi pembelian impulsif, faktor pendukung dan bagaimana masalah terjadi. Metode deskriptif-verifikatif digunakan dalam penelitian ini. Metode pengumpulan data adalah studi literatur dan lapangan. Studi lapangan mencakup observasi, wawancara, dan kuesioner struktural. Kuesioner diberikan kepada 45 konsumen di ABC Hypermarket di Jakarta Timur. Sampling sistematis digunakan sebagai teknik pengambilan sampel. Data dianalisis dengan analisis kualitatif dan analisis regresi korelasi. Analisis ini menegaskan bahwa ada pengaruh promosi penjualan terhadap pembelian impulsif di ABC Hypermarket di Jakarta Barat. Artinya, jika promosi penjualan dilakukan dengan hati-hati, itu akan meningkatkan pembelian impulsif.
\end{abstract}

*Email korespondensi: ritapalembang@gmail.com

Pedoman Sitasi: Zahara, R. (2019). Pengaruh sales promotion terhadap impulse buying pada konsumen. Jurnal Manajemen Strategi dan Aplikasi Bisnis, 2(1), 39- 44
Keywords:

sales promotion, impulsive buying

Received: 5 Jan 2019

Accepted: 1 Feb 2019

Online: 15 Feb 2019

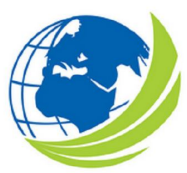

Jurnal Manajemen Strategi dan Aplikasi Bisnis, Vol 2, No.1, April 2019, pp. 39 - 44

eISSN 2655-237X 


\section{PENDAHULUAN}

Bisnis ritel merupakan keseluruhan aktivitas penjualan barang atau jasa secara langsung kepada konsumen yang digunakan untuk memenuhi kebutuhan pribadinya dan bukan digunakan untuk keperluan bisnis atau diproses lebih lanjut. Setiap perusahaan yang melakukan penjualan secara langsung kepada konsumen akhir baik produsen, grosir, maupun pengecer dapat dikatakan bertindak dalam bisnis ritel/ eceran.

Pengelolaan bisnis ritel tidak sekedar hanya membuka toko dan mempersiapkan barangbarang yang lengkap tetapi lebih dari itu. Pengelolaan bisnis ritel harus melihat dan mengikuti perkembangan teknologi agar dapat berhasil dan mempunyai keunggulan bersaing. Keunggulan yang dimiliki masing-masing pengusaha ritel ditujukan untuk memenuhi kebutuhan dan keinginan pelanggannya, akibat semakin ketatnya persaingan diantara mereka dalam penetapan harga, diskon, pengaturan lay-out yang menarik, pelayanan tambahan, fasilitas belanja dan beberapa faktor lainnya.

Terjadinya pembelian impulsif pada konsumen apabila pertama produk yang memiliki harga yang rendah, kedua produk-produk yang memiliki mass marketing, sehingga ketika berbelanja konsumen ingat bahwa produk tersebut tersebar pernah diiklankan di televisi. Ketiga adalah produkproduk dalam ukuran kecil dan mudah disimpan. Biasanya konsumen mengambil produk ini karena dianggap murah dan tidak terlalu membebani keranjang atau kereta belanjanya. Menurut AC Nielsen (2014) keberadaan impulse shopping (atau juga disebut dengan pembelian impulsif atau impulse purchasing) adalah peluang bagi peritel untuk memperkenalkan produk-produk baru. Melalui komunikasi yang efektif di dalam toko dan program promosi, hal ini akan mempengaruhi pilihan merek yang dibeli konsumen dan mendorong keputusan untuk belanja lebih banyak.

Kecenderungan pembelian impulsif merupakan trend prilaku pembelian yang marak di Pasar swalayan ABC maupun supermarket. Para peneliti dalam pemasaran konsumen dan ritel sering berpendapat bahwa pembelian impulsif mengarah pada hasil positif atau tidak berbahaya. Mereka berpendapat, misalnya pembelian impulsif tidak selalu dipandang negatif oleh konsumen, tetapi merupakan alternatif rasional untuk perilaku pencarian yang lebih memakan waktu, dan bahwa ada manfaat sosio-psikologis penting dari belanja dan pembelian impulsif"( Fenton et al., 2018). Namun peneliti lain telah menekankan hasil yang berpotensi buruk dari perilaku pembelian impulsif. Riset kesejahteraan konsumen pada pembelian kompulsif menyoroti konsekuensi negatif seperti utang kartu kredit (Joireman, Kees, \& Sprott, 2010). Mereka cenderung lebih senang berbelanja daripada membeli apa yang benar-benar mereka butuhkan. Pola ini biasa terjadi di lingkungan perdagangan sosial (Song et al., 2015), perdagangan sosial menawarkan pencarian yang nyaman (atau mengeksplorasi), membeli dan membayar (Hansen dan Olsen, 2006), dan beberapa stimulator pembelian impulsif seperti pesan kelangkaan (Song et al., 2015).

Kebanyakan promosi penjualan memang memberikan efek yang hanya bersifat jangka pendek. Bagi sebagian marketer, promosi penjualandalam bentuk hadiah yang dapat membius daya beli konsumen. Artinya, konsumen membeli hanya karena hadiah yang diberikan. Jika hadiah tersebut ditiadakan, biasanya konsumen tidak berkeinginan lagi membeli suatu merek. Namun demikian, promosi penjualan bisa menciptakan suasana yang menyenangkan dan interaktif bagi konsumen, khususnya dalam bentuk kontes ataupun demonstrasi. Penelitian ini menyelidiki pengaruh promosi terhadap perilaku pembelian impulsif konsumen di supermarket ABC. Memahami dinamika perilaku pembelian impulsif dalam perdagangan sosial penting untuk alasan teoretis dan praktis. Penelitian semacam itu dapat memperkaya literatur socialcommerce dengan mengatasi area yang belum dijelajahi: proses yang membentuk pembelian calon pengguna dalam perdagangan social.

\section{KAJIAN PUSTAKA}

Konsep Pembelian Impulsif

Setiap keputusan pembelian mempunyai motif di baliknya. Motif pembelian dapat dipandang sebagai kebutuhan yang timbul, rangsangan atau gairah. Motif ini berlaku sebagai kekuatan yang timbul yang 
ditujukan untuk memuaskan kebutuhan yang timbul. Persepsi seseorang mempengaruhi atau membentuk tingkah laku ini. Pemahaman akan motif pembelian memberikan alasan pada penjual mengapa pelanggan tersebut membeli.

Tingkah laku pembeli menunjukkan bahwa orang-orang membuat keputusan pembelian berdasarkan pada motif pembelian emosional dan rasional. Pembelian impulsif adalah adalah satu yang mendorong calon pelanggan untuk bertindak karena daya tarik atas sentimen atau gairah tertentu. Daya tarik disini berkaitan dengan pemajangan barang yang menarik sehingga seseorang berhasrat untuk melakukan suatu pembelian.

Menurut Mowen dan Minor (2001:65), definisi pembelian impulsif (adalah tindakan membeli yang dilakukan tanpa memiliki masalah sebelumnya atau maksud/niat membeli yang terbentuk sebelum memasuki toko. Intinya pembelian impulsif dapat dijelaskan sebagai pilihan yang dibuat pada saat itu juga karena perasaan positif yang kuat mengenai suatu benda. Dengan kata lain faktor emosi merupakan "tanda masuk" ke dalam lingkungan dari orang-orang yang memiliki gairah yang sama atas segala sesuatu barang. Sedangkan menurut Schiffman dan Kanuk (2007: 511) pembelian impulsif merupakan keputusan yang emosional atau menurut desakan hati. Emosi dapat menjadi sangat kuat dan kadangkala berlaku sebagai dasar dari motif pembelian yang dominan.

Promosi penjualan dan pembelian impulsif

Promosi penjualan mempunyai dampak terhadap penjualan. Ini dikarenakan trend perilaku konsumen Pertama, sensitif terhadap harga namun tetap mementingkan kualitas. Kedua, tidak menyukai suatu kelebihan yang sifatnya sama. Mereka ingin sesuatu yang lebih baik dan berbeda. Ketiga, kebutuhannya bergeser dari hal-hal yang kelihatan nyata ke sesuatu yang sifatnya tidak kasat mata. Mereka selalu menginginkan sesuatu yang eksperimental.

Tujuan dari promosi penjualan ini tentunya meningkatkan volume penjualan jangka pendek untuk perusahaan dengan menciptakan tampilan dan aktivitas yang menarik dan menimbulkan pembelian impulsif. Keuntungan lainnya yang bersifat jangka panjang adalah mendorong prilaku seseorang untuk mencoba suatu produk atau jasa untuk membuat konsumen menjadi pelanggan jangka panjang dan membina hubungan dengan perusahaan (Cummins dan Mullin, 2004: 17).

Bentuk promosi penjualan beraneka ragam, yang paling dikenal adalah POP atau point-ofpurchase. POP meliputi segala bentuk visual yang dibuat oleh pemilik merek, mulai dari pemasangan hanging display, iklan di lantai sampai penempatan produk dengan bentuk atau urutan yang menarik. Selain POP, promosi penjualan juga bisa dilakukan dalam bentuk kontes. Biasanya, para pemilik merek menempatkan stan-stan permainan di dalam pasar swalayan dan menyelenggarakan beberapa lomba berhadiah. Bentuk lain adalah dengan memberikan kupon undian yang bisa ditukar langsung dengan potongan harga atau menyediakan hadiah dan sampel yang dilampirkan pada produk yang dijual.

Promosi tersebut dapat menyebabkan pembelian impulsif. Seperti yang diketahui, para peneliti, pembelian impulsif adalah selalu disebut sebagai pembelian yang tidak direncanakan (Jeffrey \& Hodge, 2007; Tinne, 2010). Ada empat karakteristik untuk lebih menjelaskan pembelian impulsif. Pertama-tama, pembelian impulsif adalah pembelian yang tidak direncanakan di mana orang memutuskan untuk membeli barang tanpa rencana terlebih dahulu. Kedua, pembelian impulsif adalah hasil dari paparan terhadap stimulus di mana orang membeli impulsif dipicu oleh stimulus eksternal seperti desain barang atau harga yang baik. Ketiga, pembelian impulsif adalah sifat perilaku langsung di mana orang membeli tanpa mempertimbangkan pencarian informasi, evaluasi alternatif dan konsekuensi dari melakukan pembelian. Orang-orang membeli barang adalah hasil dari dorongan atau keinginan yang tiba-tiba dan kuat yang memaksa mereka untuk segera membeli. Terakhir, pembelian impulsif menyebabkan orang mengalami reaksi emosional atau kognitif seperti rasa bersalah. (Tinne, 2010; Madhavaram dan Laverie, 2004; Muruganantham \& Bhakat, 2013). 
Sebuah studi dari Zhang, Jing dan Yang (2012) menunjukkan bahwa orang lebih impulsif membeli produk virtual karena adanya voucher dan kepuasan mereka tidak dapat dipenuhi dengan segera. Mereka juga mengungkapkan bahwa pembelian impulsif konsumen lebih pada kemewahan hedonis (misalnya, Permen) daripada kebutuhan utilitarian (misalnya Beras). Harga barang dianggap sebagai faktor utama yang menyebabkan orang membeli secara impulsive apakah dalam belanja online atau belanja di dalam toko (Karbasivar \& Yarahmadi, 2011; Mesiranta, 2009). Beberapa orang melaporkan bahwa belanja online mereka dapat lebih mahal dibandingkan dengan belanja tradisional (Mesiranta, 2009). Dengan kata lain, mereka membeli secara lebih impulsif dalam belanja online daripada belanja tradisional. Selain itu, harga sangat penting bagi individu yang memiliki afektif positif untuk menjelajahi online dan mendorong pembelian impulsive terjadi (Park, Kim, Funches \& Foxx, 2012).

\section{METODE PENELITIAN}

Objek dan metode

Obyek yang diteliti dalam penelitian ini adalah Promosi Penjualan dan Pembelian impulsif pada Pasar swalayan ABCdi Di Jakarta Timur. Unit analisisnya adalah konsumen yang berbelanja di Pasar swalayan ABC Di Jakarta Timur. Metode penelitian yang digunakan dalam penelitian ini adalah metode survey dan jenis penelitiannya adalah Deskriptif Verifikatif, Variabel yang diteliti adalah promosi penjualan dan variabel terikatnya adalah pembelian impulsive

Sampel penelitian

Teknik penarikan sampel yang digunakan adalah Sistematik Random Sampling. Yang menjadi populasi dalam penelitian ini adalah 45 orang yang berbelanja di Pasar swalayan ABC di Jakarta Timur. Untuk Prosedur pengumpulan data dalam penelitian ini, dapat dilakukan dengan cara observasi, wawancara dan menggunakan kuesioner di Pasar swalayan ABC Di Jakarta Timur, kurang lebih empat bulan terhitung sejak bulan april sampai dengan Juli 2018.

Pengukuran

Pembelitian impulsive diukur menggunakan skala impulsive buying dari Rook and Fisher's (1995). Skala 9 item asli dipersingkat karena kendala ruang dalam survei. Lima item. Beberapa item seperti "Saya sering membeli barang tanpa berpikir", "Saya sering membeli barang secara spontan", "Saya melihatnya, saya membelinya' menggambarkan saya", "Lakukan saja' menggambarkan cara saya membeli barang", "Beli sekarang , pikirkan lagi nanti". Hasil uji reliabilitas memperlihatkan Alpha = 0.90 dan dinyatakan handal.

Promosi penjualan diukur berdasarkan lima item yang dikembangkan sendiri oleh peneliti berdasarkan hasil wawancara dengan produsen. Lima jenis promosi yang paling sering digunakan meliputi lokasi $\left(\mathrm{X}_{1}\right)$, Prosedur operasi $\left(\mathrm{X}_{2}\right)$, produk yang ditawarkan $\left(\mathrm{X}_{3}\right)$, harga $\left(\mathrm{X}_{4}\right)$, suasana toko $\left(\mathrm{X}_{5}\right)$, pelayanan konsumen $\left(\mathrm{X}_{6}\right)$, dan metode promosi $\left(\mathrm{X}_{7}\right)$. Hasil analisis awal menunjukkan skala yang digunakan cukup handal dengan Alpha $=0.785$.

\section{Teknik analisis}

Untuk menguji hipotesis yang diajukan, yaitu pengaruh promosi penjualan yang terdiri atas lokasi $\left(\mathrm{X}_{1}\right)$, Prosedur operasi $\left(\mathrm{X}_{2}\right)$, produk yang ditawarkan $\left(\mathrm{X}_{3}\right)$, harga $\left(\mathrm{X}_{4}\right)$, suasana toko $\left(\mathrm{X}_{5}\right)$, pelayanan konsumen $\left(\mathrm{X}_{6}\right)$, dan metode promosi $\left(\mathrm{X}_{7}\right)$ terhadap pembelian impulsif pada pasar swalayan $\mathrm{ABC}$ Jakarta Timur di gunakan regresi linear sederhana.

\section{HASIL DAN PEMBAHASAN}

Analisis deskripsi responden

Penelitian mengambil sampel sebanyak 50 orang responden. Karakteristik biografi responden meliputi: perempuan (52,1 persen) sedikit lebih banyak daripada laki-laki (47,9 persen). Secara total, 
28,3 persen responden berusia antara 30 dan 39 tahun. Kelompok kedua termasuk mereka yang berusia antara 20 dan 29 tahun (25,0 persen), diikuti oleh kelompok yang berusia antara 40 dan 49 tahun (27,7 persen) dan berusia 50 tahun ke atas (19,0 persen). Responden yang menikah (61,1 persen) lebih dari responden yang berstatus single (38,9 persen); dengan demikian, dapat diasumsikan bahwa orang yang sudah menikah lebih mungkin memiliki pengalaman sebelumnya dalam pembelian produk.

Analisis regresi

Perhitungan analisis korelasi digunakan analisis korelasi pearson diperoleh nilai korelasi sebesar 0.704. Nilai ini memiliki makna kuatnya korelasi antara promosi penjualan dengan pembelian impulsif. Perhitungan ini dilakukan untuk mengetahui besar kecilnya kontribusi promosi penjualan terhadap pembelian impulsif. Dari hasil perhitungan koefisien determinasi sebesar 49,56 dapat dikatakan bahwa pembelian impulsif terjadi karena adanya promosi penjualan. Sisanya sebesar 50,44 dipengaruhi faktor lain

Selanjutnya analisis regresi diperoleh persamaan sebagai berikut: $Y=4,2493+0,3291 \mathrm{X}$. Konstanta sebesar 4,2493 menyatakan jika promosi penjualan intervalnya adalah nol maka interval pembelian impulsif adalah 4,2493. Hal ini berarti bahwa promosi penjualan tidak dilakukan dengan baik maka pembelian impulsif dianggap tidak berhasil. Koefisien regresi X sebesar 0,3291 menyatakan bahwa promosi penjualan dilakukan sesering mungkin maka terjadinya pembelian impulsif akan tinggi,

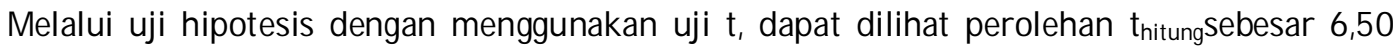
sedangkan tabel t tabel adalah 1,684. Dengan demikian diketahui bahwa hipotesis yang penulis ajukan dapat diterima karena $t_{\text {hitung }}>t_{\text {tabel }}$ yaitu, 6,50 $>1,684$. Berdasarkan kriteria uji $t$, dapat dinyatakan bahwa Ho ditolak dan H1 diterima, artinya terdapat pengaruh promosi penjualan terhadap pembelian impulsif.

\section{KESIMPULAN}

Promosi penjualan mempunyai pengaruh yang signifikan terhadap pembelian impulsif. Hal ini berarti bila promosi penjualan dilakukan sesering atau dilaksanakan dengan baik maka akan meningkatkan daya beli konsumen dalam hal ini adalah pembelian impulsif. Penelitian ini memberikan bukti untuk mendukung pandangan pembelian impulsif sebagai bentuk perilaku regulasi emosi yang terkait dengan aktivitas promosi penjualan yang dilakukan oleh perusahaan.

Implikasi etis penting berasal dari temuan ini. Mengingat hubungan antara pembelian impulsif dan kegiatan promosi, ada bukti bahwa upaya pengecer untuk mendorong pembelian impulsif melalui aktivitas promosi. Meskipun demikian, potensi biaya perilaku pembelian impulsif ini menunjukkan bahwa diperlukan intervensi kebijakan. Perusahaan perlu mempertimbangkan biaya perilaku pembelian impulsif dan ancaman lain terhadap kesejahteraan masyarakat (Fenton et al., 2018) yang menunjukkan efek negatif pembelian impulsif pada konsumen, terutama pada kesulitan keuangan dan hutang. Bukti dari penelitian ini tidak boleh diambil untuk menunjukkan bahwa bahaya melebihi manfaat untuk semua pembelian impulsif. Namun, fakta bahwa pengecer sering menggunakan berbagai program promosi dan bentuk-bentuk keterlibatan konsumen lainnya yang secara khusus menargetkan mereka yang rentan terhadap perilaku pembelian impulsif.

\section{REFERENSI}

Chung, N., Song, H. G., \& Lee, H. (2017). Consumers' impulsive buying behavior of restaurant products in social commerce. International Journal of Contemporary Hospitality Management, 29(2), 709731.

Cummins, Julian. Roddy Mullin. (2004). “Sales Promotion”. Jakarta: PPM 
Fenton-O'Creevy, M., Dibb, S., \& Furnham, A. (2018). Antecedents and consequences of chronic impulsive buying: Can impulsive buying be understood as dysfunctional self-regulation?. Psychology \& Marketing, 35(3), 175-188.

Hansen, K. and Olsen, S.O. (2006), "Impulsive buying behaviour-the role of impulse buyingtendencies and convenience orientation",Proceedings of ANZMAC 2007 Conference,University of Otago, Dunedin, Vol. 5,3 December 2007, pp. 2199-2206

Jeffrey, S. A., \& Hodge, R. (2007). Factors influencing impulse buying during an online. Electron Commerce Research, 7(3-4), 367-379

Joireman, J., Kees, J., \& Sprott, D. (2010). Concern with Immediate Consequences Magnifies the Impact of Compulsive Buying Tendencies on College Students' Credit Card Debt. The Journal of Consumer Affairs, 43(1), 155 -178

Lim, P. L., \& Yazdanifard, R. (2015). What internal and external factors influence impulsive buying behavior in online shopping?. Global Journal of Management and Business Research.

Madhavaram, S. R., \& Laverie, D. A. (2004). Exploring impulsive purchasing on the internet. Advances in Consumer Research, 31(1), 59-66

Mowen, Jihn C. Michael Minor. 2001. Consumer Behavior. Harcourt College Publisher.

Muruganantham, G., \& Bhakat, R. S. (2013). A review of impulsive buying behavior. International Journal of Marketing Studies, 5(3), 149-160

Park, E. J., Kim, e. Y., Funches, V. M., \& Foxx, W. (2012). Apparel product attributes, web browsing, and e-impulse buying on shopping websites. Journal of Business Research, 65(11), 1583-1589

Schiffman, Leon G. Leslie Lazar Kanuk. (2007). "Consumer Behavior". NY: Pearson Prentice Hall

Song, H.G., Chung, N. and Koo, C. (2015), "Impulsive buying behaviour of restaurant products in socialcommerce: a role of serendipity and scarcity message",Proceedings from PACIS 2015: The 19thPacific Asia Conference on Information Systems,Singapore,6-9 July

Tinne, W. S. (2010). Impulsive purchasing: A literature overview. ASA University Review, 4(2). Dikutip dari Lim, P. L., \& Yazdanifard, R. (2015). What internal and external factors influence impulsive buying behavior in online shopping?. Global Journal of Management and Business Research.

Zhang, X., Jing, F., \& Yang, Y. (2012). How types of online commodities affect online impulse buying. Journal of Management Science, 25(3), 69-77

\section{PROFIL PENULIS}

Rita Zahara adalah dosen di Sekolah Tinggi Ilmu Pengembangan Bisnis dan Manajemen (STIE PBM) Jakarta. 